\title{
UTILITY OF PROCALCITONIN IN THE MANAGEMENT OF FEBRILE INFANTS UNDER THAN SIX MONTHS WITH BACTERIAL INFECTIONS
}

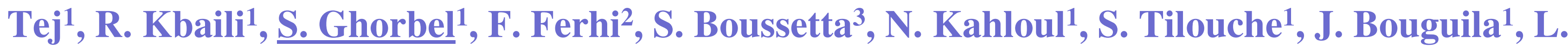
Boughamoura1.

${ }^{1}$ Farhat Hached Hospital, pediatric, Sousse, Tunisia; ${ }^{2}$ Farhat Hached Hospital, anesthesia department, Sousse, Tunisia. ${ }^{3}$ Farhat Hached Hospital, biochimestry department, Sousse, Tunisia

\section{Introduction:}

The management of febrile infants is often difficult. Procalcitonin has demonstrated his potential as an acute-phase biomarker for severe bacterial infections. The purposes of our study were: Is to compare the biologic parameters: procalcitonin,Creactive protein, white blood cell and absolute neutrophil cell counts in detecting of severe bacterial infections and to confirm that the serum PCT level was more sensitive and specific in the detection of bacterial infection.

\section{Subjects and Methods}

This was a prospective study that included infants with fever over a period of 8 months.

The diagnostic characteristics of procalcitonin,C-reactive protein, white blood cell and absolute neutrophil cell counts for detecting severe bacterial infections were described and compared for overall population and for subgroups of infants.

Laboratory tests cutoff values were calculated based on receiver operating curve analysis.

\section{Conclusion}

Our results have deduced that procalcitonin has better characteristic compared with traditional screening tests for identifying febrile infants less than 6 months with severe bacterial infection. In addition, it's a useful marker for monitoring treatment.

\section{Results}

Among 103 infants included, 43(41.75\%) was diagnosed as having a severe bacterial infections. Median of procalcitonin, C-reactive protein, white blood cells count and absolute neutrophil count were singificatively higher in this group than in non -severe bacterial infection patients (Fig1)

\begin{tabular}{|c|c|c|c|c|}
\hline & & & AUC [IC 95] & $\mathrm{p}$ \\
\hline & $\begin{array}{l}\text {-PNN de réérence } \\
\text { Ligne el }\end{array}$ & PCT ng/mL & $0,909[0,84-0,98]$ & $<0,0001$ \\
\hline & & CRP $\mathrm{mg} / \mathrm{L}$ & $0,708[0,60-0,82]$ & 0,001 \\
\hline & & GB cell $/ \mathrm{mm}^{3}$ & $0,641[0,53-0,75]$ & 0,019 \\
\hline & & PNN cell $/ \mathrm{mm}^{3}$ & $0,754[0,66-0,85]$ & $<0,0001$ \\
\hline
\end{tabular}

Fig 1 Comparison of PCT, CRP, GB and PNN ROC Curves for IBS Diagnosis.

Procalcitonin at a threshold of $0.495 \mathrm{ng} / \mathrm{ml}$ was the most effective for the identification of severe bacterial infection with a sensitivity of $83.7 \%$ and a specificity of $93.3 \%$.

A similar result was observed in infants younger than 28 days. (fig 2 )

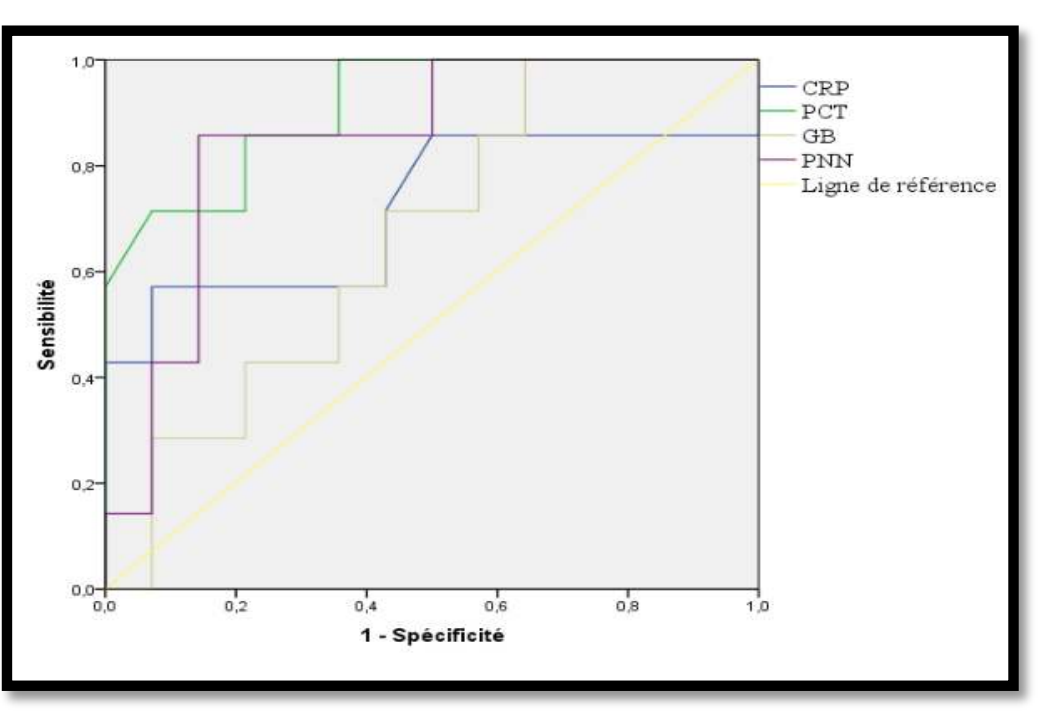

\begin{tabular}{|c|c|c|}
\hline & AUC [IC 95\%] & $p$ \\
\hline PCT ng/mL & $0,913[0,79-1]$ & 0,003 \\
\hline CRP mg/L & $0,719 \quad[0,44-0,99]$ & 0,109 \\
\hline GB cell $/ \mathrm{mm}^{3}$ & $0,663 \quad[0,43-0,90]$ & 0,233 \\
\hline PNN cell $/ \mathrm{mm}^{3}$ & $0,847 \quad[0,67-1]$ & 0,011 \\
\hline
\end{tabular}

Fig 2: ROC curves for the detection of IBS in infants aged 7-28 days.

In the multivariate analysis, procalcitonin (Odds ratio=95, $p<0.001$ ) was the most predictive marker of bacterial infections (fig3). Kinetic study of procalcitonin showed that its decrease was associated with treatment efficacy(tab I)

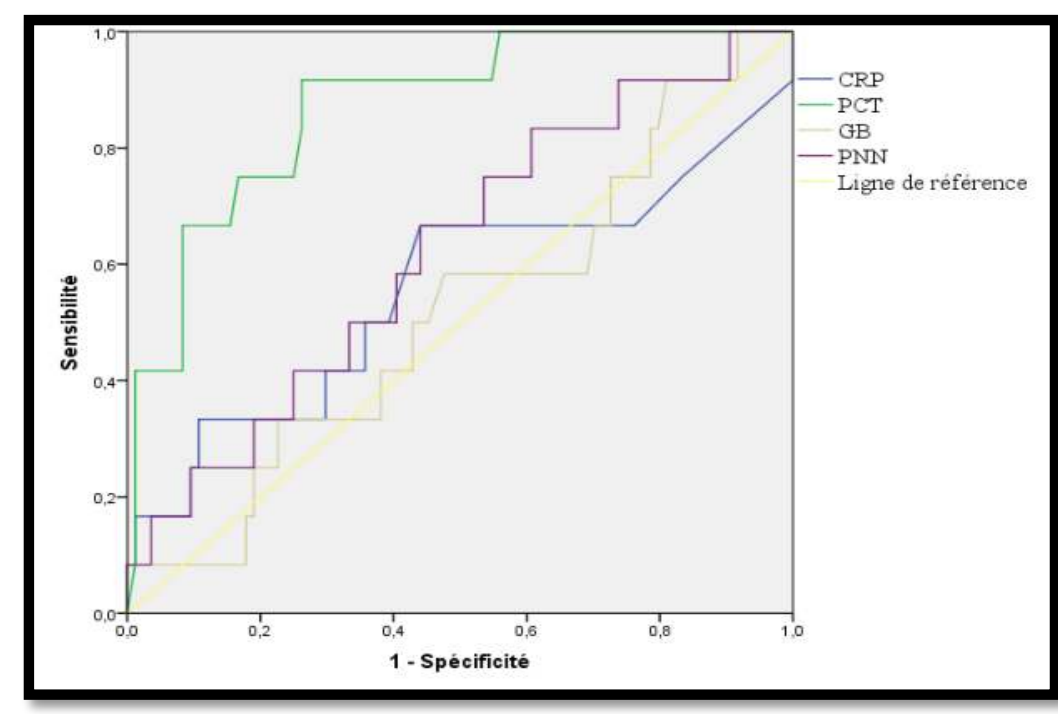

\begin{tabular}{|l|ll|c|}
\hline & AUC $[$ IC 95\%] & $p$ \\
\hline PCT $\mathrm{ng} / \mathrm{mL}$ & $0,872 \quad[0,77-0,97]$ & $<0,000$ \\
CRP $\mathrm{mg} / \mathrm{L}$ & 0,556 & {$[0,35-0,76]$} & 1 \\
GB cell/mm $\mathrm{mm}^{3}$ & 0,517 & {$[0,34-0,69]$} & 0,535 \\
PNN cell/mm $\mathrm{mm}^{3}$ & $0,622 \quad[0,46-0,79]$ & 0,851 \\
& & & 0,173 \\
\hline
\end{tabular}

Fig 3 Comparison of the ROC curves of the four parameters for IBI detection.

\begin{tabular}{|l|c|c|c|c|}
\hline \multirow{2}{*}{} & \multicolumn{2}{|c|}{$\begin{array}{c}\text { Average PCT } \\
(\mathrm{ng} / \mathrm{mL})\end{array}$} & $\begin{array}{c}\text { ATB } \\
\text { change } \\
\mathbf{N}(\%)\end{array}$ & $\begin{array}{c}\text { No ATB } \\
\text { change } \\
\mathbf{N}(\%)\end{array}$ \\
\cline { 2 - 3 } & Initiale & At control & $7(100)$ & 0 \\
\hline $\begin{array}{l}\text { Group with } \\
\text { increasing kinetics } \\
\text { (N=7) }\end{array}$ & 16,8 & 51,32 & $2(18,2)$ & $9(81,8)$ \\
\hline $\begin{array}{l}\text { Group with } \\
\text { decreasing } \\
\text { kinetics(N=11) }\end{array}$ & 1,31 & 0,28 & & \\
\hline
\end{tabular}

Table I: Kinetics of PCT and antibiotic therapy in the IBS group 